\title{
Livro - Além da Fisioterapia: Quando a Humanização É o Caminho.
}

\author{
Oishi, Ana Caroline Escorsin do Nascimento; Turbay, Érica M. do Nascimento \\ Hospital Universitário Cajuru — anacen@gmail.com
}

Introdução Anos de trabalho em meio à dor, carência, impaciência e solidão, trouxeram histórias que deixaram marcas profundas. no ambiente hospitalar o sentimento é sempre de sofrimento. em meio a essa realidade, foi observado que, ao transformar ações e formas de tratamento, poderia também transformar reações físicas, psíquicas e emocionais, otimizando atendimentos e relações. Foi observado no contato com os que padecem que muito mais que remédios e tratamentos, o que o ser humano necessita para sobreviver é aquilo que estamos deixando cada vez mais de lado. a escuta, a atenção, o tato e o contato. por outro lado, observou-se que os profissionais também se encontram despreparados para lidar com a subjetividade na assistência e para um atendimento com qualidade precisa-se de trabalhadores e gestores com um olhar que vai além da técnica. Objetivos Propor reflexões sobre as diversas facetas da dimensão humana na assistência a saúde. Demonstrar que a presença significativa e a comunicação eficaz são fundamentais para um atendimento que valoriza a real atenção ao próximo. Métodos a obra foi baseada em casos clínicos vivenciados entre os anos de 2009 a 2011. Essas histórias aguçaram a percepção e levaram a otimização do tratamento de cada paciente atendido. Resultados Durante os atendimentos de cada caso houve uma resposta específica em um tempo específico, o que demonstra que devemos levar em conta o ser humano em sua totalidade. Muitas vezes a doença não se instala apenas em um corpo físico, o que necessita de uma proximidade do profissional ao seu paciente. Sendo assim, observou-se a importância da escuta, do toque, do lado humano das relações. um importante resgate às condutas ensinadas há muitos séculos. Conclusões: a intenção deste livro foi propor reflexões sobre como a conduta, comunicação e presença significativa podem influenciar positivamente no tratamento. Foi também colocar o ser humano como o centro da discussão e não a doença. a complexidade das dores que atingem o corpo e sucumbem à alma faz com que reflitamos sobre cada indivíduo a nossa volta e sobre a nossa própria existência. Nossa lição foi perceber como é complexo ser simples, ser apenas humanos, ser a nossa essência. Nosso objetivo é passar às pessoas que praticam a assistência à saúde a importância de manternos humanos saudáveis para assistir humanos fragilizados. a busca pela qualidade é uma constante e para que tenhamos qualidade nos serviços e processos precisamos do olhar de gestores e profissionais para um atendimento mais humano. Considerando que todo indivíduo tem o direito a assistência à saúde e neste processo deve ser respeitado de forma íntegra e genuína. Somente em um ambiente que valoriza a real atenção ao próximo poderemos acolher, confortar e auxiliar no restabelecimento da saúde.

Oishi, Ana Caroline Escorsin do Nascimento; Turbay, Érica M. do Nascimento. Livro - Além da Fisioterapia: Quando a Humanização É o Caminho.. In: Anais do Congresso Internacional de Humanidades \& Humanização em Saúde [= Blucher Medical Proceedings, num.2, vol.1]. São Paulo: Editora Blucher, 2014. ISSN 2357-7282

DOI 10.5151/medpro-cihhs-10246 